\title{
LANDAU AND GRÜSS TYPE INEQUALITIES FOR INNER PRODUCT TYPE INTEGRAL TRANSFORMERS IN NORM IDEALS
}

\section{DANKo R. Jocić, ĐorĐE KRTINić And MOHAMmad SAL Moslehian}

Abstract. For a probability measure $\mu$ and for square integrable fields $\left(\mathscr{A}_{t}\right)$ and $\left(\mathscr{B}_{t}\right)(t \in \Omega)$ of commuting normal operators we prove Landau type inequality

$$
\begin{aligned}
\left\|\int_{\Omega} \mathscr{A}_{t} X \mathscr{B}_{t} d \mu(t)-\int_{\Omega} \mathscr{A}_{t} d \mu(t) X \int_{\Omega} \mathscr{B}_{t} d \mu(t)\right\| \| \\
\leqslant\left\|\sqrt{\int_{\Omega}\left|\mathscr{A}_{t}\right|^{2} d \mu(t)-\left|\int_{\Omega} \mathscr{A}_{t} d \mu(t)\right|^{2}} X \sqrt{\int_{\Omega}\left|\mathscr{B}_{t}\right|^{2} d \mu(t)-\left|\int_{\Omega} \mathscr{B}_{t} d \mu(t)\right|^{2}}\right\| \|
\end{aligned}
$$

for all $X \in \mathcal{B}(\mathscr{H})$ and for all unitarily invariant norms $\|\cdot\| \|$.

For Schatten $p$-norms similar inequalities are given for arbitrary double square integrable fields. Also, for all bounded self-adjoint fields satisfying $C \leqslant \mathscr{A}_{t} \leqslant D$ and $E \leqslant \mathscr{B}_{t} \leqslant F$ for all $t \in \Omega$ and some bounded self-adjoint operators $C, D, E$ and $F$, and for all $X \in \mathcal{C}_{\|\cdot\| \cdot \|}(\mathscr{H})$ we prove Grüss type inequality

$$
\left\|\int_{\Omega} \mathscr{A}_{t} X \mathscr{B}_{t} d \mu(t)-\int_{\Omega} \mathscr{A}_{t} d \mu(t) X \int_{\Omega} \mathscr{B}_{t} d \mu(t)\right\| \leqslant \frac{\|D-C\| \cdot\|F-E\|}{4} \cdot\|X\| .
$$

More general results for arbitrary bounded fields are also given.

Mathematics subject classification (2010): Primary 47A63; Secondary 46L05, 47B10, 47A30, 47B15. Keywords and phrases: Landau type inequality, Grüss type inequality, Gel'fand integral, norm inequality, elementary operators, Hilbert modules.

\section{REFERENCES}

[1] D. Andrica And C. BADEA, Grüss' inequality for positive linear functionals, Period. Math. Hungar. 19, 2 (1988), 155-167.

[2] S. BAnić, D. IlišEVIĆ AND S. VAROŠ AnEC, Bessel-and Grüss-type inequalities in inner product modules, Proc. Edinb. Math. Soc. (2) 50, 1 (2007), 23-36.

[3] R. Bhatia, Matrix Analysis, Graduate texts in Mathematics, 169, Springer-Verlag, New York, Inc., 1997.

[4] C. Buse, P. Cerone, S. S. Dragomir And J. Roumeliotis, A refinement of Grüss type inequality for the Bochner integral of vector-valued functions in Hilbert spaces and applications, J. Korean Math. Soc. 43, 5 (2006), 911-929.

[5] X. L. Cheng And J. Sun, A note on the perturbed trapezoid inequality, J. Inequal. Pure Appl. Math. 3, 2 (2002), Article 29, 7 pp.

[6] J. Diestel and J. J. Uhl, Vector Measures, Math. Surveys, 15, Amer. Math. Soc. Providence, RI, 1977.

[7] S. S. Dragomir, A Grüss type discrete inequality in inner product spaces and applications, J. Math. Anal. Appl. 250, 2 (2000), 494-511.

[8] S. S. Dragomir, Advances in inequalities of the Schwarz, Grüss and Bessel type in inner product spaces, Nova Science Publishers, Inc., Hauppauge, NY, 2005. 
[9] A. M. FInK, A treatise on Grüss' inequality, Analytic and geometric inequalities and applications, 93-113, Math. Appl., 478, Kluwer Acad. Publ., Dordrecht, 1999.

[10] G. GRÜSs, Über das Maximum des absoluten Betrages von $\frac{1}{b-a} \int_{a}^{b} f(x) g(x) d x-$ $\frac{1}{(b-a)^{2}} \int_{a}^{b} f(x) d x \int_{a}^{b} g(x) d x$, Math. Z. 39 (1935), 215-226.

[11] D. IlišEvić And S. VArošAnEC, Grüss type inequalities in inner product modules, Proc. Amer. Math. Soc. 133 (2005), 3271-3280.

[12] S. Izumino, J. E. PeČArić And B. Tepeš, Some extensions of Grüss' inequality, Math. J. Toyama Univ. 26 (2003), 61-73.

[13] D. R. Jocić, Cauchy-Schwarz norm inequalities for weak*-integrals of operator valued functions, J. Funct. Anal. 218 (2005), 318-346.

[14] D. R. Jocić, Interpolation norms between row and column spaces and the norm problem for elementary operators, Linear Alg. Appl. 430 (2009) 2961-2974.

[15] D. R. Jocić, Multipliers of elementary operators and comparison of row and column space Schatten p-norms, Linear Alg. Appl. 431 (2009), 2062-2070.

[16] X. Li, R. N. Mohapatra And R. S. Rodriguez, Grüss-type inequalities, J. Math. Anal. Appl. 267, 2 (2002), 434-443.

[17] E. Landau, Über einige Ungleichungen von Herrn G. Grüss, Math. Z. 39 (1935), 742-744.

[18] E. LANDAU, Über mehrfach monotone Folgen, Prace Mat.-Fiz. XLIV (1936), 337-351.

[19] A. MC. D. Mercer And P. R. Mercer, New proofs of the Grüss inequality, Aust. J. Math. Anal. Appl. 1, 2 (2004), Art. 12, 6 pp.

[20] D. S. Mitrinović, J. E. PeČAriĆ And A. M. Fink, Classical and New Inequalities in Analysis, Kluwer Academic, Dordrecht, 1993.

[21] M. S. Moslehian AND R. RaJić, A Grüss inequality for n-positive linear maps, Linear Algebra Appl. 433 (2010), 1555-1560.

[22] G. J. MurPhy, $C^{*}$-algebras and Operator Theory, Academic Press, Boston, 1990.

[23] I. PERIĆ AND R. RAJIĆ, Grüss inequality for completely bounded maps, Linear Algebra Appl. 390 (2004), 287-292.

[24] P. F. Renaud, A matrix formulation of Grüss inequality, Linear Algebra Appl. 335 (2001), 95-100.

[25] N. UJEVIĆ, A generalization of the pre-Grüss inequality and applications to some quadrature formulae, J. Inequal. Pure Appl. Math. 3, 1 (2002), Article 13, 9 pp. 